\title{
Synthesis of $\boldsymbol{\beta}$-SiC Whiskers from Silica Black Ore
}

\author{
Shiro SHIMADA, Nobuyuki AKAZAWA and Kazuhiko KUDO* \\ Department of Applied Chemistry, Faculty of Engineering, Hokkaido University, Nishi 8, Kita 13, Kita-ku, Sapporo-shi 060 \\ *Nopporo Branch, Hokkaido Industrial Research Institute, 76, Yoyogi-machi, Ebetsu-shi 069
}

\author{
ブラックシリカ鉱石からの $\beta$-SiC ウイスカーの合成 \\ 嶋田志郎・赤沢信之·工藤和彦* \\ 北海道大学工学部応用化学科, 060 札幌市北区北 13 条西 8 丁目 \\ *北海道工業試験場野幌分場, 069 江別市野幌代々木町 76
}

\begin{abstract}
Beta-silicon carbide whiskers ( $\beta$-SiCw) were synthesized by heating powdered "silica black" ore, which consisted mainly of $\mathrm{SiO}_{2}$, carbon, $\mathrm{Al}_{2} \mathrm{O}_{3}, \mathrm{Fe}_{2} \mathrm{O}_{3}$, in a closed graphite crucible in argon at $1673 \mathrm{~K}$ for $3.6 \times 10^{4} \mathrm{~s}$. When the samples were dispersed in cotton fibers before heating, a large concentration of whiskers resulted, which formed agglomerates several hundred microns in size. The individual whiskers were on average $0.3 \mu \mathrm{m}$ in diameter and $30 \mu \mathrm{m}$ long with an aspect ratio of 100 . A droplet of composition, $\mathrm{Fe} \mathrm{e}_{2.5} \mathrm{Si}$, was formed on a tip of each whisker, suggesting the VLS growth mechanism.
\end{abstract}

[Received May 30, 1996; Accepted July 17, 1996]

Key-words : $\beta$-SiC, Whiskers, VLS growth mechanism, Silica black

1. Introduction

Beta-silicon carbide whiskers, $\beta$-SiCw, are important materials for reinforcement of various ceramic or glass matrices because of their high strength, good resistance to chemical attack and good thermal shock resistance at high temperatures. $\mathrm{SiCw}$ is produced by three main methods; carbothermal reduction of silica in the presence of iron as a catalyst,1)-4) decomposition of organic silicon compounds, ${ }^{5,6)}$ and reaction between organic silicon halides and $\mathrm{CCl}_{4} \cdot{ }^{7)}$ Of these, the first method, which was pioneered by Lee and Cutler, ${ }^{1)}$ has the potential for highly economical production of $\mathrm{SiCw}$.

So-called "silica black" ore is sedimentary siliceous material occurring in black mudstone in the "Kami-noKuni" region of south Hokkaido in Japan. Chemical analysis (Table 1) shows it contains free silica as the major component with minor amounts of alumina, carbon and iron oxide. It has previously been used as additions to concrete blocks, for soil improvement or as a snow melter. Our attention was drawn to silica black ore, because it contains the necessary components for the formation of $\mathrm{SiC}$, in addition to iron oxide, a catalyst which promotes the growth of

Table 1. Chemical Analysis of Silica Black Ores (mass\%)

\begin{tabular}{lr}
\hline $\mathrm{SiO}_{2}$ & 81.4 \\
$\mathrm{Al}_{2} \mathrm{O}_{3}$ & 6.4 \\
carbon & 5.0 \\
$\mathrm{~K}_{2} \mathrm{O}$ & 1.7 \\
$\mathrm{TiO}_{2}$ & 1.2 \\
$\mathrm{Fe}_{2} \mathrm{O}_{3}$ & 0.5 \\
$\mathrm{MgO}$ & 0.5 \\
ig. loss & 3.3 \\
\hline
\end{tabular}

$\mathrm{SiCw}$. Therefore, we attempted to synthesize $\mathrm{SiCw}$ solely by heating the silica black samples. This note describes the first successful synthesis of $\mathrm{SiCw}$ from silica black ore.

\section{Experimental}

The silica black ore was ground to pass through a $5 \mu \mathrm{m}$ sieve. X-ray analysis showed the diffraction pattern of $\alpha$ quart $z$ with additional unidentified small peaks. The starting samples were ( $i$ ) the ground ore alone, (ii) ground ore + graphite (about $5 \mu \mathrm{m}$ particle size) or active carbon, (iii) ground ore + cotton; the use of cotton for growth of $\mathrm{SiCw}$ has been reported by Yamada. ${ }^{8}$ The cotton was essentially 95\% cellulose and produced amorphous carbon when heated in the absence of air. The weight of the cotton was reduced to about one tenth the original weight after heating. In case (iii), the samples were spread in the raw cotton fibers and then rolled, and carbonized prior to the growth experiment in a flowing nitrogen at $973 \mathrm{~K}$ for $7.2 \times 10^{3} \mathrm{~s}$. All the samples of ( $\mathrm{i}$ ) to (iii) were fired in a graphite crucible with a tight lid ( $13 \mathrm{~mm}$ in diameter $\times 33 \mathrm{~mm}$ in length) in a flowing argon $\left(0.83 \times 10^{-6} \mathrm{~m}^{3} \cdot \mathrm{s}^{-1}\right)$ at $1673 \mathrm{~K}$ for $3.6 \times$ $10^{4} \mathrm{~s}$. After the growth experiment, all the samples were heated again in air at $973 \mathrm{~K}$ for $1.08 \times 10^{4} \mathrm{~s}$ to remove excess carbon.

The whiskers were examined by optical and scanning electron microscopy (SEM; JEOL, JSM $35 \mathrm{CF}$ ). Some whiskers were mounted on a $\mathrm{Cu}$-grid for examination by transmission electron microscopy (TEM; JEOL, $2000 \mathrm{ES}$ ). Chemical analysis of droplets formed on the tips of the whiskers was carried out by energy dispersive X-ray analysis (EDX). The phases in the whiskers and residues obtained after the experiment were identified by X-ray diffraction (XRD).

\section{Results and discussion}

Table 2 shows the representative experimental results for the growth of $\mathrm{SiC}$ whiskers. No whiskers were formed in open crucibles. The silica black samples ( i ) produced a small number of whiskers on the inner wall and lid of the crucible. The whiskers were normally thick and short (5 $\mu \mathrm{m} \times 0.7 \mu \mathrm{m})$ (Exps. 2 and 3), but occasionally, fibrous whiskers were produced (Exp. 1). After the growth experiment, the residue was a black, solidified melt. 

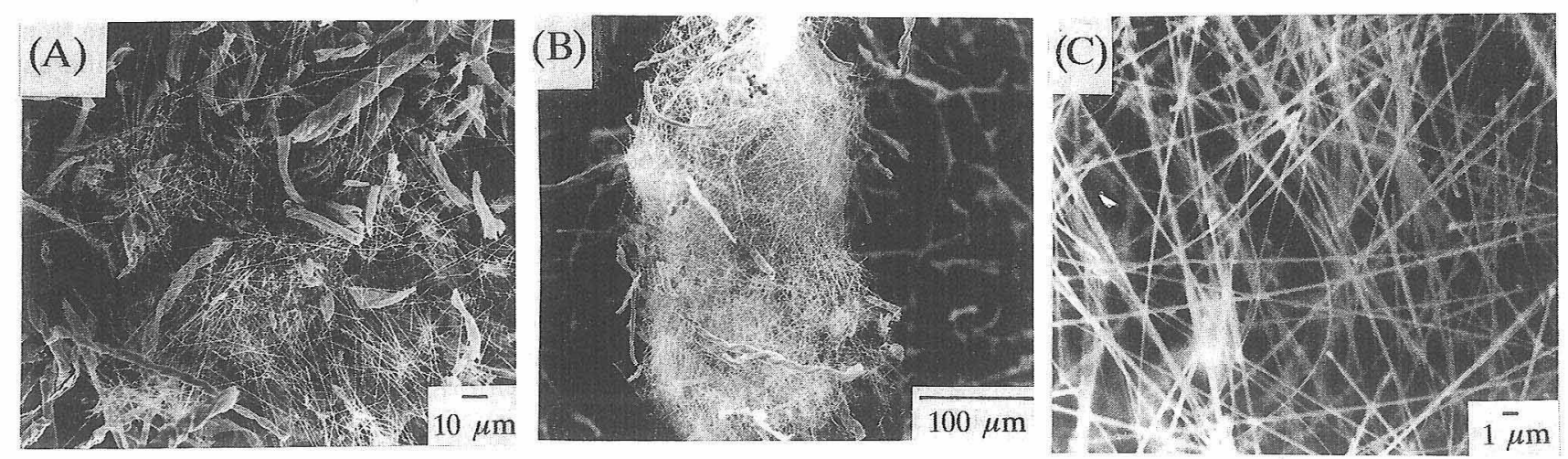

Fig. 1. SEM photographs of $\mathrm{SiCw}$ grown in cotton. (A) SiCw grown in Exp. 7; (B) an agglomerate of SiCw grown in Exp. 9 and (C) an enlarged photo of $(B)$.

Table 2. Experimental Results for Growth of SiC Whiskers

\begin{tabular}{rllcc} 
Exp. Samples & Sample weight $(\mathrm{g})$ & \multicolumn{1}{c}{ Form } & Size $^{{ }^{11}(\mu \mathrm{m})}$ \\
\hline 1 & S.B. ${ }^{2}$ & 0.3 & fibrous whiskers & - \\
2 & S.B. & 0.5 & whiskers & $0.7 \times 5$ \\
3 & S.B. & 1.0 & whiskers & $0.7 \times 5$ \\
4 & S.B. $+\mathrm{G}^{*}$ & $0.30+0.1$ & whiskers & $0.3 \times 20$ \\
5 & S.B.+G & $0.30+0.3$ & fibrous whiskers & - \\
6 & S.B.+G & $0.30+0.6$ & fibrous whiskers & - \\
7 & S.B.+C & $0.10+0.42$ & whiskers & $0.3 \times 30$ \\
8 & S.B.+C & $0.20+0.45$ & whiskers & $0.3 \times 40$ \\
9 & S.B.+C & $0.33+0.45$ & whiskers & $0.3 \times 30$ \\
10 & S.B.+C & $0.53+0.45$ & whiskers & $0.3 \times 20$ \\
\hline
\end{tabular}

Growth condition $1673 \mathrm{~K}$ for $3.6 \times 10^{4} \mathrm{~s}$ in a closed graphite crucible; *1, average size; ${ }^{*}$, silica black; $* 3$, graphite; ${ }^{*}$, cotton,

The amount of carbon necessary for conversion of $\mathrm{SiO}_{2}$ in silica black to $\mathrm{SiC}$ is calculated to be about 45 mass $\%$, according to the Reaction (1);

$$
\mathrm{SiO}_{2}(\mathrm{~s})+3 \mathrm{C}(\mathrm{s})=\mathrm{SiC}(\mathrm{s})+2 \mathrm{CO}(\mathrm{g})
$$

Carbon was added to the silica black samples, because their natural carbon content is insufficient for the complete conversion to $\mathrm{SiC}$ (Exps. 4-6). The addition of graphite to the silica black samples in the weight ratio $1 / 3$ produced a few whiskers, which grew both in the sample and on the wall and lid of the crucible (Exp. 4). Increasing the amount of graphite decreased the number of whiskers, and tended to produce a fibrous morphology (Exps. 5 and 6 ). The residue was grayish green in color and found by XRD to be mostly $\mathrm{SiC}$. The use of active carbon instead of graphite caused no change in the form and number of whiskers.

The silica black samples heated with the cotton produced a number of whiskers on the fibers and in the spaces between them (Exps. 7-10). Even a small amount of silica black produced sparse whiskers within the cotton (Exp. 7) (Fig. 1(A)); increasing the amount of silica black increased the number of whiskers (Exps. 8 and 9), which gathered in the cotton into agglomerates several hundred microns in size (Fig. 1(B)). As shown in the enlarged photo (Fig. 1(C)), the whiskers are thin and long $(30 \mu \mathrm{m} \times 0.3$ $\mu \mathrm{m})$, with an aspect ratio of 100 , and have a droplet on their tip. The whiskers also grew on the inner wall and lid of the crucible, and were confirmed by optical microscope to be almost the same size as those grown in the cotton. With samples weight of $0.53 \mathrm{~g}$, the number of whiskers was decreased (Exp. 10). Increasing the sample weight to $1.0 \mathrm{~g}$ tended to produce fibrous clusters or balls, probably because the supersaturation increased with increasing the vapour pressures of $\mathrm{SiO}$ and $\mathrm{CO}$ formed by Reaction (2), resulting in cluster growth. ${ }^{3)}$

$$
\mathrm{SiO}_{2}(\mathrm{~s})+\mathrm{C}(\mathrm{s})=\mathrm{SiO}(\mathrm{g})+\mathrm{CO}(\mathrm{g}) \text {. }
$$

It is considered that the cotton not only compensates for deficiency of carbon in the samples but also provides spaces for transport of gases such as $\mathrm{SiO}$ and/or $\mathrm{CO}$. XRD and EDX confirmed that the cotton is changed to $\beta$-SiC.

It was found by TEM observation that the whiskers have a droplet on their tip (Fig. 2(A)), and also exhibit many black lines normal to the growth direction. These are due to stacking faults with planes normal to the growth direction, as reported by Seo and Koumoto. ${ }^{9)}$ Constricted regions with an absence of black lines were also observed on the whiskers, as shown by an enlarged photo of a circled portion of the whisker (Fig. 2(B)). Electron diffraction performed on a whisker showed the $(h, h, h)(h=1,2,3,4)$ spots, indicating that the growth direction of the whisker was [111].

Several mechanisms have been proposed for the synthesis of $\mathrm{SiC}$, all of which involve initial stage formation of silicon monoxide by Reaction (2). This reaction should readily occur in the silica black samples, which contain intimately mixed silica and carbon. SiO formation may be followed by whisker growth, according to Reaction (3),1),3)

$$
\mathrm{SiO}(\mathrm{g})+2 \mathrm{C}(\mathrm{s})=\mathrm{SiCw}+\mathrm{CO}(\mathrm{g})
$$

In Reactions (2) and (3), C(s) comes from the black ore (Exps. 1-3), the graphite powders (Exps. 4-6), and the cotton (Exps. 7-10) in addition to the graphite crucible. The graphite crucible provides sites for the growth of $\mathrm{SiCw}$.
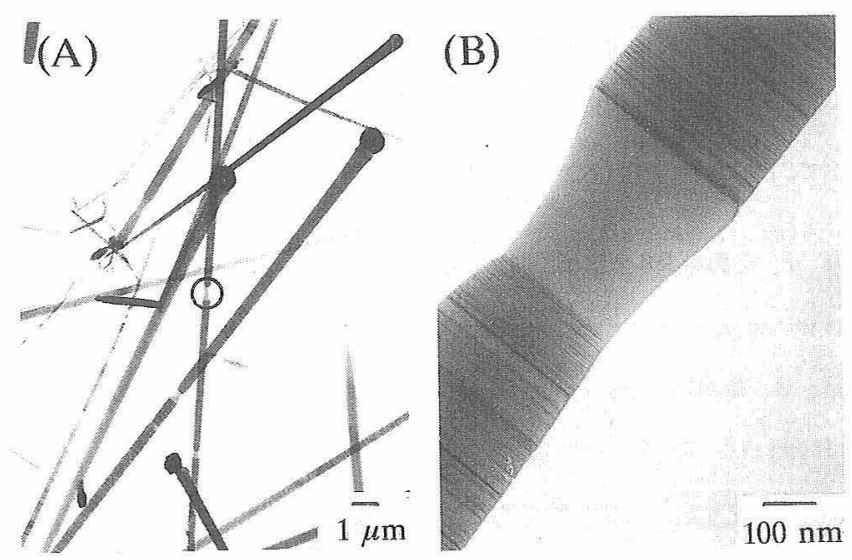

Fig. 2. TEM photographs of $\mathrm{SiCw}$. (A) SiCw grown in Exp. 9 and (B) an enlarged photo of the circled area in the photo (A). 


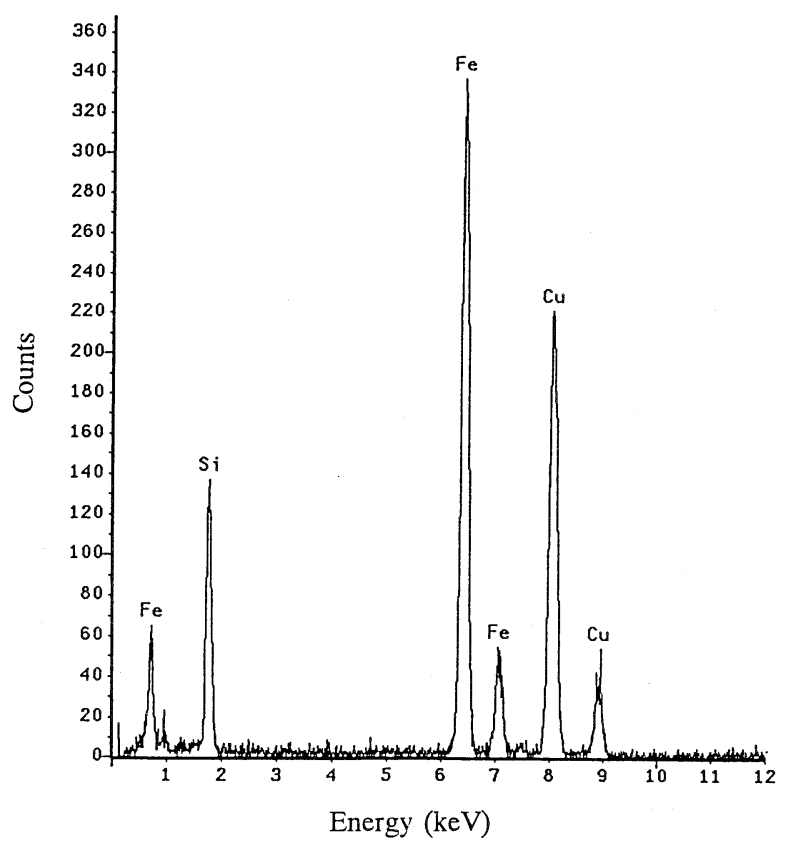

Fig. 3. EDX spectrum of the droplet formed on the tip of a whisker.

Almost all the whiskers had a $0.5-1.0-\mu \mathrm{m}$ droplet on their tip (Fig. 2(A)). The droplets were analyzed by TEMEDX, which showed them to contain elemental $\mathrm{Fe}$ and $\mathrm{Si}$ (56 and $43 \mathrm{~mol} \%$ on the average, respectively), which cor- responds to the composition $\mathrm{Fe}_{2.5} \mathrm{Si}$; $\mathrm{Cu}$ signals came from the $\mathrm{Cu}$-TEM grid. This silicide composition is different from the $\mathrm{FeSi}$ and $\mathrm{Fe}_{3} \mathrm{Si}$ reported by Narciso-Romero and Rodriguez-Reinoso ${ }^{10)}$ and Cutler, ${ }^{11)}$ respectively. The droplets occurring on the tip of each whisker in the present work suggest the VLS mechanism, in which gaseous $\mathrm{SiO}$ and $\mathrm{CO}$ dissolve in a droplet, ${ }^{3)}$ to produce $\mathrm{SiCw}$ also by Reaction (4) after the rapidly occurring initial Reaction (2). $\mathrm{SiO}(\mathrm{g})+3 \mathrm{CO}(\mathrm{g})=\mathrm{SiCw}+2 \mathrm{CO}_{2}(\mathrm{~g})$

Further work for thickening $\mathrm{SiCw}$ should be necessiated, and it has to be examined how uniform quality $\mathrm{SiCw}$ can be grown in every growth run from silica black ore.

\section{References}

1) G. Lee and I. B. Cutler, Am. Ceram. Soc. Bull., 54, 195-98 (1975).

2) G. A. Bootsma, W. F. Knippenberg and G. Verspui, J. Crystal Growth, 11, 297-309 (1971).

3) J. V. Milewski, F. D. Gac, J. J. Petrovic and S. R. Skaggs, J. Mater. Sci., 20, 1160-66 (1985).

4) R. V. Krishinarao, M. M. Godokhindi, P. G. Lyengar Mukunda and M. Chakraborty, J. Am. Ceram. Soc., 74, 2869-75 (1991).

5) H. P. Kirchner and P. Knoll, J. Am. Ceram. Soc., 46, 299-300 (1963).

6) A. Addamiano, J. Crystal Growth, 58, 617-22 (1982)

7) N. Setaka and K. Ajiri, J. Am. Ceram. Soc., 55, 540 (1972).

8) S. Yamada, Seramikkusu, 24, 300-06 (1989).

9) W.-S. Seo and K. Koumoto, J. Am. Ceram. Soc., in press.

10) F. J. Narciso-Romero and F. Rodriguez-Reinoso, J. Mater. Soc., 31, 779-84 (1996).

11) I. B. Cutler, US. Pat. 3754976 (1973). 